\title{
HEALTHY LIFESTYLE: SOCIAL REPRESENTATION OF TYPE 2 DIABETES MELLITUS PATIENTS
}

Nêda Lyan Souto Lopes De Queiroz ${ }^{1} \mathbb{\text { iD }}$, Paula Paulina Costa Tavares 2 (iD Nelia De Oliveira Damasceno Da Silva ${ }^{3} \boldsymbol{\Delta}$ (iD), Marcia Oliveira Damasceno 4 (iD), Gina Andrade Abdala 5 (iD), Maria Dyrce Dias Meira 6 (iD

${ }^{1}$ Master in health promotion UNASP/SP, Brazil

2 Master in health promotion, professor of the Nursing course at Faculdade Adventista da Bahia, Brazil

${ }^{3}$ Student of the professional master's degree in health promotion UNASP/SP, Brazil

${ }^{4}$ Master in health promotion, Brazil

$5 \mathrm{PhD}$ in Science, Professor of the professional master's program in health promotion at the Adventist University Center of São Paulo UNASP/SP, Brazil

${ }^{6} \mathrm{PhD}$ in Science, Professor of the professional master's program in health promotion at the Adventist University Center of São Paulo UNASP/SP, Brazil

DOI: https://doi.org/10.29121/granthaalayah.v8.i11.2020.2381

Article Type: Research Article

Article Citation: Nêda Lyan Souto Lopes De Queiroz, Paula Paulina Costa Tavares, Nelia De Oliveira Damasceno Da Silva, Marcia Oliveira Damasceno, Gina Andrade Abdala, and Maria Dyrce Dias Meira. (2020). HEALTHY LIFESTYLE: SOCIAL REPRESENTATION OF TYPE 2 DIABETES MELLITUS PATIENTS. International Journal of Research GRANTHAALAYAH, 8(11), 185-194. https://doi.org/10.29121/granthaa layah.v8.i11.2020.2381

Received Date: 06 November 2020

Accepted Date: 22 November 2020

Keywords:

Type 2 Diabetes Mellitus

Healthy Lifestyle

Health Promotion
ABSTRACT

Objective: to identify the social representations of type 2 Diabetes Mellitus patients on the effect of an educational intervention to guide the adoption of healthy habits.

Method: This was a qualitive study, where semi-structured intervies. Semi-structured interviews were applied after an educational intervention and were analized using the Collective Subject Discourse technique, based on the Theory of Social Representations.

Results: 21 patients participated. In the analysis of the three questions, eleven Central Ideas emerged: "Aspects that contribute to health"; "There are difficulties for putting it into practice"; "Everything positive, including the attention received"; "It is possible, everything is there in nature"; "It is possible, but it does not replace the drugs"; "It is not always possible, it depends on some factors"; "If the person doesn't want it, everything is difficult"; "You can use them all"; "Mainly sun, physical activity, healthy eating "; "I like water very much"; "Trust in God is essential".

Final considerations: the participants recognized the importance of adopting a healthy lifestyle and highlighted the positive results of adopting healthy habits. 
Healthy Lifestyle: Social Representation of Type 2 Diabetes Mellitus Patients

\section{INTRODUCTION}

According to the World Health Organization (WHO) Diabetes Mellitus (DM) consists of a important chronic disease, which occurs when the pancreas does not produce enough insulin or when the body cannot effectively use the insulin it produces. [1] Type 2 Diabetes Mellitus (DM2) represents 90\% of diabetes cases and has reached alarming proportions, coming to be considered an epidemic, as the number of people who will become diabetic in the world has the prospect of rising from 425 in 2017 to 642 million in 2045 . This estimate is mainly due to the increase of the disease in developing countries, such as Brazil, where the number will increase by $62 \%$, going from 26 to 42 million in 2045. [2], [3]

Patients with diabetes, especially the type 2, face several adjustment difficulties, which affect the subjective perception of their life condition. This perception can change depending on what phase of development the complications related to the disease are in. It's important to emphasize that this chronic condition persists throughout life and usually comes with other comorbidities that have a direct impact on autonomy, mobility and quality of life. The impact of these complications translates into an increase in the years of life lost due to functional disability, representing almost 5\% of the disease burden in Brazil. [4]

As it is a multifactorial and difficult to manage disease, the prognosis of DM2 depends mainly on lifestyle changes, which in turn, must be associated with adherence to drug treatment. Assessing the interference of lifestyle in the development of DM2 complications has been a challenge, since there is low adherence on the part of these patients to the programs that are offered. It is of great importance to involve patients in programs that encourage the adoption of a healthy lifestyle, so that they have the opportunity to live not only longer but also with higher quality. [5]

It is worth mentioning that the economic impact caused by diabetes in relation to productivity and direct costs to the health system has become a public health concern, with important social consequences. Higher incidences of cardio and cerebrovascular diseases, blindness, renal failure and amputation, among others, will predictably continue to represent an overload on the health systems of countries with varying rates of economic development. This burden is undoubtedly greater in developing countries, reflecting both direct and indirect costs related to premature mortality, temporary and permanent disabilities resulting from complications. [6] The implementation and increase of coverage and quality of primary care, can result in a better control of diabetes and help reduce the number of hospitalizations. [7]

The present study aimed to identify the social representations of patients with DM2 on the effect of an educational intervention to guide the adoption of healthy habits.

\section{METHOD}

This is a descriptive, exploratory study, developed through a semi-structured interview in a qualitative approach, using the Collective Subject Discourse (CSD) [8] technique for data analysis, based on the Social Representation Theory (SRT). [9] The technique CSD analysis tool was developed to apprehend collective perceptions in a given social context. It can be defined as a methodological strategy that integrates data collection and analysis techniques of a predominantly qualitative nature. [10]

The SRT, in turn, expands the possibility of apprehending common sense by adopting the CSD analysis technique, as its association leads to a more comprehensive understanding of reality, allowing the analysis of the expression of beliefs and values that influence and are influenced by behaviors and attitudes that determine the reality that is being studied. Dealing with communication in everyday life surrounded by plots and social relations in all domains and areas of knowledge. Common sense is both transformative and resistant to change and these aspects are empirical systems and fully capable of being observed. [11]

The sample was intentional and of voluntary adherence, initially composed of 32 patients with DM2, registered in an FHU in the city of Cachoeira, in the Recôncavo Baiano - Brazil. All were invited by the respective Community Health Agents (CHA) to participate in an educational intervention that aimed to guide the adoption of healthy habits. Out of this population, only 21 participated in the eight weekly meetings in which the Spirituality and Health Workshops (SHW) [12] strategy, held in August and September 2016, was applied.

At each meeting, blood pressure and blood pressure levels were checked, as well as body weight. The workshops were structured with moments of spiritual reflection, seminars of each of the "Eight Natural Remedies", and also 
practical activities to encourage adherence to healthy habits, as shown in Chart 1. The proposal was based on presenting and encouraging the adoption of healthy habits, referred to by White as "Eight Natural Remedies" (ENR). [13] These habits are part of the Adventist lifestyle and include guidelines on: proper use of water and clean air, exposure to the sun, rest, natural food, practice of regular physical activity, trust in God and balance in all day-to-day choices. [12] In a systematic review research conducted by Damaceno (2018) [14], the influence of healthy habits, related to ENR is shown, with emphasis on Food and Physical Activity, as they present a greater influence on glycemic control.

Chart 1: OES Program on Healthy Eating

Goals:

- Reflect on Health Integrality.

- Reflect on the Health / Disease process in the context of Natural Laws.

- Associate food with health and spirituality.

\begin{tabular}{|c|c|c|}
\hline Moment & Content & Strategy / Material \\
\hline $\begin{array}{l}\text { Introduction } \\
10 \text { min. }\end{array}$ & $\begin{array}{l}\text { Reception and information about the day's } \\
\text { activities }\end{array}$ & $\begin{array}{l}\text { Welcome the participants. Praise the } \\
\text { achievements of the past week. }\end{array}$ \\
\hline $\begin{array}{l}\text { Heating } \\
20 \text { min }\end{array}$ & Relaxing and inspiring instrumental music. & $\begin{array}{l}\text { Listen to the music with your eyes closed } \\
\text { wondering what the music conveys. }\end{array}$ \\
\hline $\begin{array}{l}\text { Development } \\
50 \text { min. }\end{array}$ & $\begin{array}{l}\text { Theme: Food and Health } \\
\text { Individual moment: } \\
\text { Daniel's story devotional reading. } \\
\text { Group moment: } \\
\text { Characterizing the spiritual needs of the } \\
\text { participants: } \\
\text { - Write a short story, based on real facts, about } \\
\text { binge eating } \\
\text { - Each group must plan and dramatize a "real } \\
\text { case" story from another group. }\end{array}$ & $\begin{array}{l}\text { Material: Sheet of paper, clothes and other } \\
\text { small accessories for dramatization. } \\
\text { Guide the dynamics, encouraging the group to } \\
\text { take ownership of the text and reflect while it } \\
\text { is being presented. }\end{array}$ \\
\hline $\begin{array}{l}\text { Synthesis } \\
30 \text { min }\end{array}$ & $\begin{array}{l}\text { Short lecture: "The importance of food for } \\
\text { health and its relationship with spirituality". } \\
\text { Synthesis of the statements of the groups and } \\
\text { production of new knowledge. Invite a } \\
\text { nutritionist to give the lecture. }\end{array}$ & $\begin{array}{l}\text { Invite a nutritionist to give the lecture. } \\
\text { Dialogue exhibition: } \\
\text { Power point. }\end{array}$ \\
\hline $\begin{array}{l}\text { Closing } \\
10 \text { min. }\end{array}$ & $\begin{array}{l}\text { Partial evaluation of the workshop. } \\
\text { Task of the week: } \\
\text { - reading the text: Daniel's story. } \\
\text { - Make a daily food record } \\
\text { Open moment for the participants to speak. }\end{array}$ & $\begin{array}{l}\text { Individual statements about what you thought } \\
\text { about the session. } \\
\text { Keywords: choices, habit, pleasure, health. } \\
\text { Source. }\end{array}$ \\
\hline
\end{tabular}

Source: Adapted from Abdala; Meira and Teixeira (2015).

After the intervention, a semi-structured interview was conducted with guiding questions and a questionnaire was filled out with sociodemographic, clinical and anthropometric information. Each participant previously signed the Free and Informed Consent Form (FICF).

After transcription, the discursive content was subjected to the CSD [8], [10] analysis technique, which consisted of highlighting the Key Expressions (KE), containing the representation of each of the participants, and then assembling them around several Central Ideas (CI) categorized in order to answer the guiding questions formulated, building a representative discourse of the community as if it were just one participant.

This study followed the research recommendations involving human subjects and was approved by the Research Ethics Committee under opinion No. 1,542,117. 


\section{RESULTS AND DISCUSSION}

The study included 21 patients with DM2 who had lived in the municipality of Cachoeira for more than 5 years and were under medical supervision at a Family Health Unit (USF) in the region, aged between 29 and 85 years. In the researched group there was a predominance of elderly people aged between 60 and 85 years (62\%), the majority were women (81\%) and blacks (47.6\%) and brown (42.9\%) with low educational level (76\%). Among the participants, only 38.1\% did not have comorbidities associated with DM2. Based on the Body Mass Index (BMI) table, it was possible to identify that nine of them were within normal parameters, seven were classified as overweight, four of them with grade 1 obesity and only one with grade 2 .

To achieve the proposed objectives, the analysis of the interviews allowed the construction of speeches containing the Social Representations (SR) of the researched group. After the educational intervention, it was sought to know the participants' opinion about healthy lifestyle, and the difficulties in incorporating the ENR practices in their daily lives. The three guiding questions allowed the construction of $11 \mathrm{CI}$ and their respective CSD, presented below:

Question 1: What are the positive or negative aspects perceived in the way of life presented during the eight educational meetings?

In response to this question, the participants expressed themselves in a way that enabled the composition of three $\mathrm{CI}$, which were constituted as a representation of the researched group, according to the respective CSD (Table 1).

Table 1: Representation of the Central Ideas (CIs) of the first question

\begin{tabular}{|c|c|}
\hline Central Idea - CI & Collective Subject Discourse - CSD \\
\hline CI A - 71\% & CSD \\
\hline $\begin{array}{c}\text { Aspects that } \\
\text { contribute to health } \\
\text { (15 KE) }\end{array}$ & $\begin{array}{c}\text { For me there is nothing negative, because everything was for the sake of my health! } \\
\text { I learned that water is essential, food, sunlight and trust in God is very good for health. } \\
\text { A lot of things are free, but I don't always use it. I am trying to improve. } \\
\text { Before, I never walked, but now I do, even if it's only half an hour and that has made a } \\
\text { difference in my life. The air, things that we don't even value, it helps us to be healthy, } \\
\text { so it was positive, without a doubt. I didn't know all that: sleep, and those things in } \\
\text { nature are good to have a better life }\end{array}$ \\
\hline $\begin{array}{c}\text { CI B - 33\% } \\
\text { to putting it into } \\
\text { practice (7 KE) }\end{array}$ & $\begin{array}{c}\text { It was good, but sometimes the problems don't let us put it into practice, it is still good } \\
\text { to hear, I understood what is best for me. } \\
\text { Sometimes there are things that we don't follow properly, but I know that everything is } \\
\text { correct. The negative side is just that it is difficult to do everything right and also the } \\
\text { lack of effort of many people }\end{array}$ \\
\hline $\begin{array}{c}\text { CSD } \\
\text { It was all positive, } \\
\text { including the attention } \\
\text { received (2 KE) }\end{array}$ & $\begin{array}{c}\text { God only knows how good it was these days, the attention, the instruction, to hear } \\
\text { everything about nature and what it gives. It is God taking care of our health. } \\
\text { He doesn't want anyone sick. It was all positive, even the attention received from you. I } \\
\text { didn't think anyone cared that much about us. Not even the family does that! }\end{array}$ \\
\hline
\end{tabular}

Source: research data

It was possible to observe that participation in the educational program through workshops has become very important for each participant, as they have come to know better how to adopt a healthy lifestyle. The participants recognized that there are many positive aspects related to the proposed lifestyle and the use of ENR and realized that these resources, being offered by nature and free of charge, can be easily adopted, depending on the will of each one. The perception and the recognition of the importance of lifestyle and the knowledge acquired were positive aspects and generated some changes in the behavior pattern of the participants.

A study carried out in China points out that the systematic practice of physical exercise is an important ally in non-pharmacological treatment for DM2. There was an improvement in quality of life and sleep. Sleep time and 
Nêda Lyan Souto Lopes De Queiroz, Paula Paulina Costa Tavares, Nelia De Oliveira Damasceno Da Silva, Marcia Oliveira Damasceno, Gina Andrade Abdala, and Maria Dyrce Dias Meira

quality are shown to have a regulating effect on glucose tolerance. In addition, sleep disorders increase the difficulty of controlling blood glucose levels that can directly affect sleep quality. [15]

Participants understood that the adoption of ENR did not imply interrupting or changing the use of conventional drugs without a medical prescription. The representation regarding these aspects was very prevalent, as this belief has been well disseminated, since the action of the medication is effective and well accepted by the population in general. In addition to drug prescription, health professionals should be sought to assist in the process of lifestyle changes, which can contribute to the reduction of diabetes symptoms and complications. [16]

There is a contradiction in the Brazilian reality in relation to eating habits. While information on healthy eating has been widely and frequently transmitted, the population, however, still eats incorrectly, even knowing the losses resulting from this habit. [17] The practice of physical exercise also improves glycemic control, reducing risk factors for cardiovascular diseases by contributing to weight loss and improving general well-being. [18]

It is important to highlight in the representations the discourse "there are things that we don't follow properly [...] it is difficult to do everything right", which refers to adversity and everyday problems, making it difficult to adopt healthy habits. The older age of the participants, which ranged from 60 to 80 years, also leads to a reflection on the difficulty of changing habits, probably because there are deep-rooted beliefs that diabetes control should include only pharmacological drugs. It is noteworthy that lifestyle management is a fundamental aspect in the treatment of diabetes.[18]

Question 2: Do you think it is possible, difficult or impossible to adopt the habits that have been proposed based on the natural remedies? Talk a little about it.

The answers to this question demonstrate the participants' representation regarding the difficulties to adopt the proposed lifestyle. ECH were classified according to the four CI abstracted from the respective discursive contents that made up the CSD presented in Table 2.

Table 2: Representation of the Central Ideas (CI) of the second question

\begin{tabular}{|c|c|c|}
\hline Central Idea - CI & Collective Subject Discourse - CSD \\
\hline CI A - 57\% & CSD \\
\hline $\begin{array}{c}\text { It's possible, it's all } \\
\text { there in nature (12 } \\
\text { KE }\end{array}$ & $\begin{array}{c}\text { I think it is possible, it is not difficult. It's possible because everything is there in nature, } \\
\text { it's free. At the health center, people don't talk about it, they only talk about pharmacy } \\
\text { medicines, and you can't think that only the medicine will solve it. What I learned here } \\
\text { was good, it teaches people to live longer. I never thought of being cared for like this ... } \\
\text { That's why I liked it! I remember everything that was said. Staying in the sun is good, } \\
\text { water is good, fresh air is also good! It's just knowing how to use each one of them, you } \\
\text { know? }\end{array}$ \\
\hline $\begin{array}{c}\text { CI B - 10\% } \\
\text { does not replace the } \\
\text { doctor's medicines } \\
\text { (2 KE) }\end{array}$ & $\begin{array}{c}\text { It is possible, it is true, if I could, I would not even take medication anymore, but for } \\
\text { example, sugar, pressure, you know, you cannot go without medication. I feel good } \\
\text { because I take the doctor's medicine, there are somethings that we have to do. We have } \\
\text { to take this sugar remedy, and then I can't stop taking it, but thank God everything is } \\
\text { fine. }\end{array}$ \\
\hline CI C - 24\% & $\begin{array}{c}\text { CSD } \\
\text { It is not always } \\
\text { possible, it depends some factors } \\
\text { (5 KE) }\end{array}$ & $\begin{array}{c}\text { It is not impossible, some things are difficult and others are easier! Because the person } \\
\text { who is already used to a different lifestyle, until it adapts, it takes a while. Remembering } \\
\text { everything that was taught at the meetings seems easy, but when you get there it is not } \\
\text { so much, you know? It is not always possible to remember to sunbathe, to breathe in the } \\
\text { air, to sleep at the right time, and the worry does not stop. Sometimes the family, } \\
\text { relatives help or get in the way, you know! The old person ... She tries to remember, but } \\
\text { she can't. To lead this life like not eating this, not eating that ... There is only one thing } \\
\text { that I find difficult, is to live more in this fruit and vegetable business, because there are } \\
\text { days when we don't even have fruit at home. I speak the truth straight away, days when } \\
\text { we have no money to buy something, then it fails. It is not impossible, but you have to } \\
\text { trust God and pray ... If not, it is difficult! }\end{array}$ \\
\hline
\end{tabular}


Healthy Lifestyle: Social Representation of Type 2 Diabetes Mellitus Patients

\begin{tabular}{|c|c|}
\hline CI D - 5\% & CSD \\
\hline $\begin{array}{c}\text { If the person does not } \\
\text { want, everything is } \\
\text { difficul (1 KE) }\end{array}$ & $\begin{array}{c}\text { Oh, um, I don't know, everything that was said at the meetings works and it's good! I } \\
\text { think you can do it, but if the person doesn't want to, then everything is difficult! But, } \\
\text { you have to try and think that if you live it, you can improve your health. }\end{array}$ \\
\hline
\end{tabular}

Source: research data

The speeches refer to different opinions regarding the possibility of adopting healthy habits. While some expressed ease, others pointed out difficulties, ranging from a personal decision to economic status, revealing several factors that influence decision-making and adherence to a healthy lifestyle.

Food is configured as a legitimate object of social analysis and also as an object for comprehension of the implicit premises of living in society. In this sense, it is configured as a theme that, when approached, needs strategies that consider the cultural and regional aspects of the diabetic and his family, as eating habits are built over a lifetime, with sociocultural influence. [19], [20] Given this, it is understood that society also develops from the resources offered by nature, around which they organize themselves into family and work groups. According to the interviewees' statements, the natural remedies that were advised are "free and easily accessible". This assertion indicates a reflective thought regarding the use of them for health promotion.

Lifestyle change is a fundamental part of the treatment for chronic diseases, but habits are social and culturally constructed behaviors throughout life, wrapped in symbolic aspects that materialize the tradition in the form of rites and taboos, being difficult to modify. In this sense, the issue of personal preferences and socio-cultural traditions that influence eating habits stands out as an example, especially when customs involve eating foods rich in carbohydrates, often hindering changes in the preparation of a differentiated diet for diabetics. [21], [22]

Food is one of the fundamental aspects for existence, and depending on the point of view, food can be good or not, it can be pleasing to the eye or not, or it can still have satisfactory odors or not. These preferences will be directly influenced by the culture in which the person lives or was raised. [20] The will of the individual is essential and, therefore, working with education or food re-education of the population is a strategy for raising awareness. However, it is necessary to consider the barriers that the DM2 patient encounters to develop self-care practices, which include unfavorable socioeconomic status and inadequate knowledge about the disease. [23]

Although the representation present in the CI D discourse "If the person does not want to, everything is difficult" is from just one interviewee, it is strongly anchored in common sense and validated by scholars who consider motivational factors to be essential for any behavioral change. [24] The interviewees in this research stated that "everything is a matter of their own will", that is, in order for this will to be stimulated, the guidelines of health professionals must be clear and persuasive so that they can awaken people's motivation to adopt healthy lifestyle habits.

The participation of a multidisciplinary team is of fundamental importance to encourage those who are still deciding whether or not to change their lifestyle. As a multisystemic disease, DM2 requires multidisciplinary, interactive and collaborative treatment, in order to influence the adoption of healthy habits for better metabolic control. It should be noted that the factors that favor health are modifiable, since they relate to lifestyle and automatically come into association with various behavioral aspects such as: balanced diet, regular physical exercise, good interpersonal relationships and reduced stress. Therefore, if people are informed about this information, they may be increasingly interested in a healthy way of life, since they all want to live more and better. [25], [26]

Question 3: In your daily life, which of the "Eight Natural Remedies", presented at the meetings, do you think you can use to improve your health?

The representation of patients with DM2 in response to this question brought together four CI corresponding to the CSD shown in Table 3

Table 3: Representation of Central Ideas (CI) of the third question

\begin{tabular}{|c|c|}
\hline Central Idea - CI & Collective Subject Discourse - CSD \\
\hline CI A - 57\% & CSD \\
\hline $\begin{array}{c}\text { You can use all } \\
\text { (12 KE) }\end{array}$ & $\begin{array}{c}\text { I think you can use the natural remedies every day, we just don't remember that. The sun } \\
\text { and fresh air. The others too. They are all good, without them we will be nothing, they all } \\
\text { serve as benefits to health. I understood that they are good for me and everything is there, }\end{array}$ \\
\hline
\end{tabular}


Nêda Lyan Souto Lopes De Queiroz, Paula Paulina Costa Tavares, Nelia De Oliveira Damasceno Da Silva, Marcia Oliveira Damasceno, Gina Andrade Abdala, and Maria Dyrce Dias Meira

\begin{tabular}{|c|c|}
\hline & $\begin{array}{c}\text { you just have to use it. God gave them to improve our health. The most difficult thing is } \\
\text { sleep, because the other "things" in life get in the way. }\end{array}$ \\
\hline $\begin{array}{c}\text { CI B - 48\% } \\
\text { physical activity, } \\
\text { healthy eating (10 } \\
\text { KE) }\end{array}$ & $\begin{array}{c}\text { The sun is very good and has great benefits! We even use it unintentionally! This week, it } \\
\text { was very sunny, I was there. In many places it is not possible to have the sun as we do here. } \\
\text { Physical activity is also very good! I like to play sports, sometimes I do, even though I don't } \\
\text { have enough time, but I have been trying to, for my own good! And healthy eating too... } \\
\text { And, I didn't even know that food was medicine, much less sun and air... I never imagined! }\end{array}$ \\
\hline $\begin{array}{c}\text { CSD } \\
\text { I really like water } 24 \%\end{array}$ & $\begin{array}{c}\text { I use water, I really like water! Water is one of the natural assets that I like the most, that I } \\
\text { use continuously. Look, water is very good! I take it every day. Because the water cleans } \\
\text { everything, washes everything, right? Everything is clean! There are people who like to } \\
\text { drink juice, drink soda, eat juice, and I don't, my satisfaction is to drink water. Most people } \\
\text { need to drink more water, it's always there, just drink it. }\end{array}$ \\
\hline $\begin{array}{c}\text { CSD } \\
\text { Trust in God is } \\
\text { essential (3 KE) }\end{array}$ & $\begin{array}{c}\text { Only trust in God, right, because the person having God in life, has everything. Only God to } \\
\text { heal the person, and with confidence in God you can do everything, you can exercise, eat } \\
\text { less sweet stuff, you can get everything. So, I will do everything I learned! Trusting in God I } \\
\text { used to do already, so now I just have to do the rest. }\end{array}$ \\
\hline
\end{tabular}

Source: research data

Most respondents reported that they recognized the possibility of adopting the use of all ENR, since, "it's all there, you just have to use it". However, in the same speech they showed concern about sleep, which was one of the natural remedies they mentioned as being a little more difficult. Sleep pattern can be affected by age, psychological and physiological conditions, culture and environmental factors, among other things.[27] Thus, it is imperative to be aware of the sleep pattern and how the ENR can contribute to improve its quality.

The participants in this research highlighted some of the natural remedies that could be better incorporated into their daily lives, such as food and physical activity. Lifestyle interventions that combine the consumption of plant foods with regular exercise can be even more effective and significantly reduce the incidence of diabetes. [28]

Another aspect that stands out in the representation of the researched group concerns the lack of knowledge about the importance of sunlight and clean air for health. They claimed that they did not know that sunlight and clean air were considered natural medicines, nor that food was medicine.

Vitamin D deficiency correlates with the prevalence of diabetes, which makes it essential for health professionals to recognize this deficiency as a risk factor and encourage adequate exposure to the sun, as an approach to increase vitamin D levels. [29], [30]

With regard to air quality, long-term exposure to air pollution is associated with an increased risk of diabetes, particularly in younger, overweight or obese individuals. The global number of diabetes attributable to air pollution is significant. Thus, reducing exposure to pollutants results in substantial health benefits.[30]

It was also observed that the participants believed that "Trust in God" is a natural resource that enhances the action of any treatment, that is, they believed that religious practice could contribute to everything in their lives, including diabetes control. The way in which each individual interprets the existence of God may or may not contribute to the adoption of healthy habits. Thus, the religiosity of individuals can positively influence glycemic control, self-care, depression and anxiety, resulting in a better quality of life for patients with DM2.

\section{FINAL CONSIDERATIONS}

This research addressed issues pertinent to the formation of healthy living habits, which are based on the "Eight Natural Remedies" (water, air, sun, rest, diet, physical exercise, temperance and trust in God). It was based on the 
premise that these resources, when properly used, constitute a lifestyle that promotes health in a holistic way and positively interfere in people's lives, especially those with DM2, reducing the risk of their complications.

In the speeches of the participants, the idea prevailed that it is possible to follow a lifestyle based on the adoption of healthy habits, as they realized that all the ENR are available in nature. They expressed the understanding that it is not complicated to adopt these habits, for the most part, as access to natural remedies occurs in an easy, practical and economically viable way.

The individuals stated that everything that happened during the educational intervention was positive, for they felt included, and received attention and care. Because they felt welcomed, they were more inclined to adopt the oriented health practices. They emphasized that the new lifestyle favored changes in the referred health status. However, in other aspects, perceived objectively and subjectively in the speeches, they conditioned the adoption of healthy habits to the power exercised by the will, that is, the individual must "want and wish to change".

They also realized that, along with the individual's desire to change, the difficulties in adopting the ENR as their daily habits, were sometimes influenced by the support and adherence of family members. They also recognized the importance of associating the adoption of healthy lifestyle habits with allopathic treatment to control the disease.

Trust in God appears as a relevant and recognizedly important factor for the participants, but they stressed that it is conditioned to the spiritual dimension of each individual, regardless of their religion. The participants' understanding and internalization of the importance of these practices in daily life was clear and noticeable. However, factors such as low education and low standard of living have made it difficult to adopt such practices as an additional resource to control glycemic rates and avoid complications resulting from DM2.

\section{SOURCES OF FUNDING}

This research received no specific grant from any funding agency in the public, commercial, or not-for-profit sectors.

\section{CONFLICT OF INTEREST}

The author have declared that no competing interests exist.

\section{ACKNOWLEDGMENT}

None.

\section{REFERENCES}

[1] World Health Organization. Global reporton diabetes. WHO. Available in: http://apps.who.int/iris/bitstream/10665/204871/1/9789241565257_eng.pdf?ua=1

[2] International Diabetes Federation. Diabetes Atlas. International Diabetes Federation. 8 th Edition, 2015. Available in: http://diabetesatlas.org/IDF_Diabetes_Atlas_8e_interactive_ES/

[3] Ministério da Saúde (BR). Departamento de Vigilância de Doenças e Agravos não Transmissíveis e Promoção da Saúde. Vigitel Brasil 2017: vigilância de fatores de risco e proteção para doenças crônicas por inquérito telefônico - Brasília: Ministério da Saúde, 2018. Available in: https://bvsms.saude.gov.br/bvs/publicacoes/vigitel_brasil_2017_vigilancia_fatores_riscos.pdf

[4] Costa AF, Flor LS, Campos MR, Oliveira AF, Costa MFS, Silva RS, et al Burden of type 2 diabetes mellitus in Brazil. Carga do diabetes mellitus tipo 2 no Brasil. Cad Saude Publica. 2017;33(2):e00197915. https://doi.org/10.1590/0102-311X00197915.

[5] Flor LS, Campos MR. The prevalence of diabetes mellitus and its associated factors in the Brazilian adult population: evidence from a population-based survey. Rev Bras Epidemiol. 2017;20(1):16-29. https://doi.org/10.1590/1980-5497201700010002.

[6] Global Burden of Desease. Disease and Injury Incidence and Prevalence Collaborators. Global, regional, and national incidence, prevalence, and years live with disability for 310 diseases and injuries, 1990- 2015: a 
Nêda Lyan Souto Lopes De Queiroz, Paula Paulina Costa Tavares, Nelia De Oliveira Damasceno Da Silva, Marcia Oliveira Damasceno, Gina Andrade Abdala, and Maria Dyrce Dias Meira

systematic analysis for the Global Burden of Disease Study 2015. Lancet. 2016;388(10053):1545-603. https://doi.org/10.1016/S0140-6736(16)31678-6.

[7] Ribeiro TH, Magri CL, Santos AL. Hospitalizações por diabetes mellitus em adultos e relação com expansão da atenção primária no Paraná. Saúde e Pesqui. 2019;12(2):323-33. https://doi.org/10.17765/21769206.2019v12n2p323-331.

[8] Lefèvre F, Lefèvre AMC. O discurso do sujeito coletivo: um novo enfoque em pesquisa qualitativa. Caxias do Sul: Educs, 2003.

[9] Moscovici S. Representações sociais: investigações em psicologia social. Petrópolis: Vozes; 2003.

[10] Lefèvre F, Lefèvre AMC. O sujeito coletivo que fala. Interface (Botucatu). 2006;10(20):517-24. https://doi.org/10.1590/S1414-32832006000200017.

[11] Minayo MCS. O desafio do conhecimento: pesquisa qualitativa em saúde. 14å . ed. São Paulo: Hucitec; 2015.

[12] Abdala GA, Meira MDD, Teixeira CA. Oficinas de Espiritualidade e Saúde. São Paulo: Casa Publicadora Brasileira; 2015.

[13] White EG. A ciência do bom viver. 10. ed. Tatuí, SP: Casa Publicadora Brasileira; 2013.

[14] Damaceno, MO. Estilo de Vida Saudável e controle do Diabetes Mellitus: Revisão Sistemática. [Dissertação] Centro Universitário Adventista de São Paulo, Programa de Mestrado em Promoção da Saúde, 2018.

Yang C, Zhong X, Liang $\mathrm{H}$. Effect of different intensity aerobic exercise on sleep quality in patients with type 2 diabetes. Journal of Physics: Conference Series. 2019;1213(5):1-8. https://doi.org/10.1088/17426596/1213/5/052011.

[15] Reddy, PH. Can Diabetes Be Controlled by Lifestyle Activities? Current research in diabetes \& obesity jornal. 2017;1(4):555-68. https://www.ncbi.nlm.nih.gov/pmc/articles/PMC5792082/

[16] Lindermann IL, Oliveira RR, Mendoza-Sassi RA. Difficulties in ensuring a healthy diet among primary health care users and associated factors. Ciênc saúde coletiva [online]. 2016;21(2):599-610. https://doi.org/10.1590/1413-81232015212.04262015.

[17] American Diabetes Association. Lifestyle management: Standards of Medical Care in Diabetes. Diabetes Care. 2019;42 Suppl 1:S46-S60. https://care.diabetesjournals.org/content/diacare/42/Supplement_1/S46.full.pdf

[18] Azevedo E. Alimentação, sociedade e cultura: temas contemporâneos. Sociologias [online]. 2017;19(44):276307. https://doi.org/10.1590/15174522-019004412.

[19] Souza LO, Figueiredo WS, Machado MLT. As práticas de educação em diabetes vivenciadas no sus: uma discussão da literatura com ênfase na atenção primária à saúde. Rev APS. 2017;20(3):423-433. https://doi.org/10.34019/1809-8363.2017.v20.15801

[20] Borba AKOT, Marques APO, Ramos VP, Leal MCC, Arruda IKG, Ramos RSPS. Factors associated with elderly diabetic adherence to treatment in primary health care. Ciênc \& Saúde Colet. 2018;23(3):953-61. Disponivel em: https://doi.org/10.1590/1413-81232018233.03722016.

[21] Abuelmagd W, Osman BB, Håkonsen H, Jenum AK, Toverud EL. Experiences of Kurdish immigrants with the management of type 2 diabetes: a qualitative study from Norway. Scandinavian Journal of Primary Health Care. 2019;37(3):345-352. https://doi.org/10.1080/02813432.2019.1639911.

[22] Dias EG, Nunes MSL, Barbosa VS, Jorge AS, Campos LM. Comportamentos de pacientes com diabetes tipo 2 sob a perspectiva do autocuidado. J Health Sci [Internet]. 2017;19(2):109-13. http://dx.doi.org/10.17921/24478938.2017v19n2p109-113.

[23] Araujo E, Araújo ESS, Silva LF, Moreira TMM, Almeida PC, Freitas MC, Guedes MVC. Nursing care to patients with diabetes based on King's Theory. Rev Bras Enferm. 2018;71(3):1157-63. https://doi.org/10.1590/00347167-2016-0268

[24] Souza MAH, Porto EF, Souza EL, Silva KI. Profile of lifestyle of older elderly persons. Revista Brasileira de Geriatria e Gerontologia. 2016;19(5):819-26. https://doi.org/10.1590/1809-98232016019.150224.

[25] Saint-Pierre C, Prieto F, Herskovic V, Sepúlveda M. Team Collaboration Networks and Multidisciplinarity in Diabetes Care: Implications for Patient Outcomes. Journal of Biomedical and Health Informatics. 2020;24(1):319-29. https://doi.org/10.1109/JBHI.2019.2901427.

[26] Troynikov O, Watson CG, Nawaz N. Sleep environments and sleep physiology: A review. Journal of thermal biology. 2018;78:192-203. <https://doi.org/10.1016/j.jtherbio.2018.09.012>. 
[27] Davis BC, Jamshed H, Peterson CM, Sabaté J, Harris RD, Koratkar R, et al. An Intensive Lifestyle Intervention to Treat Type 2 Diabetes in the Republic of the Marshall Islands: Protocol for a Randomized Controlled Trial. Frontiers in nutrition. 2019;6:1-13. https://doi.org/10.3389/fnut.2019.00079.

[28] Aatsinki SM, Elkhwanky MS, Kummu O, et al. Fasting-induced transcription factors repress vitamin D bioactivation, a mechanism for vitamin D deficiency in diabetes. Diabetes. 2019;68(5):918-31. https://doi.org/10.2337/db18-1050.

[29] Alloubani A, Akhu-Zaheya L, Samara R, Abdulhafiz I, Saleh A, Altowijri A. Relationship between Vitamin D Deficiency, Diabetes, and Obesity. Diabetes \& Metabolic Syndrome: Clinical Research\& Reviews. 2019;13(2)1457-61. https://doi.org/10.1016/j.dsx.2019.02.021

[30] Yang BY, Qian ZM, Li S, et al. Ambient air pollution in relation to diabetes and glucose-homoeostasis markers in China: a cross-sectional study with findings from the 33 Communities Chinese Health Study. Lancet Planet Health. 2018;2:e64-e73.: https://doi.org/10.1016/S2542-5196(18)30001-9. 